\title{
Cow urine as a potential source for struvite production
}

\author{
Meghanath Prabhu $\cdot$ Srikanth Mutnuri
}

Received: 26 May 2013/ Accepted: 25 December 2013/Published online: 5 March 2014

(C) The Author(s) 2014. This article is published with open access at Springerlink.com

\begin{abstract}
Background Rock phosphate deposits are non-renewable and are facing a decline. Due to this, phosphate fertilizers are going to be limited in future. Struvite is a crystalline mineral substance containing equimolar amount $(1: 1: 1)$ of magnesium ammonium and phosphate ions $\left(\mathrm{MgNH}_{4} \mathrm{PO}_{4}\right.$ $6 \mathrm{H}_{2} \mathrm{O}$ ), a good source of phosphorus and a slow release fertilizer. In the present study it was crystallized from cow urine using brine as cheap source of magnesium. Cow urine and brine was mixed at different proportion to find out the optimum concentration for struvite crystallization. Crystallized struvite was characterized by X-ray diffraction, thermogravimetric and differential thermal analysis, Fourier transform infrared spectroscopy and scanning electron microscopy and energy dispersive spectroscopy.

Results The ratio of 1:0.5 cow urine and brine mixing gave the best quality struvite at $\mathrm{pH} \mathrm{9.} \mathrm{The} \mathrm{analysis} \mathrm{of}$ struvite for phosphate, magnesium and ammonium ions showed 5.85, 3.16, and $0.56 \%$ respectively. The fertilizer potential of struvite was evaluated on the growth of Vigna radiata. The best growth was observed in the pots where struvite was added at a concentration of $2 \mathrm{~g} / \mathrm{kg}$ of soil.
\end{abstract}

Conclusion Struvite is a good source of phosphate and it can be recovered from livestock waste such as cow urine. Struvite can be made from a renewable source for a sustainable agricultural development. Theoretically at the yield of $40 \mathrm{~g} / \mathrm{L}$ a total of 12,176 tons struvite could be made per day all over India for fertilizer use.

Keywords Brine $\cdot$ Cow urine $\cdot$ Crystallization . Fertilizer $\cdot$ Phosphate $\cdot$ Struvite

\section{List of abbreviations}

DAP Diammonium posphate

$\mathrm{MgCl}_{2} \quad$ Magnesium chloride

$\mathrm{NaCl} \quad$ Sodium chloride

FTIR Fourier transform infrared spectroscopy

TG-DTA Thermogravimetric and differential thermal analysis

SEM-EDAX Scanning electron microscopy and energy dispersive spectroscopy

XRD X-ray diffraction
M. Prabhu

Applied and Environmental Biotechnology Laboratory, Department of Biological Sciences, Birla Institute of Technology and Science, Pilani, K. K. Birla Goa Campus, Goa, India e-mail: prabhumeghanath66@gmail.com

S. Mutnuri $(\bowtie)$

Department of Biological Sciences, Birla Institute of Technology and Science, Pilani, K. K. Birla Goa Campus, Near NH17B,

Bypass Road Zuarinagar, 403726 Goa, India

e-mail: srikanth.mutnuri@gmail.com;

srikanth@goa.bits-pilani.ac.in

\section{Introduction}

Phosphorus (chemical symbol P) is an essential nutrient element for all life forms and its consumption along with its price is increasing day by day all over the world. Rock phosphate in sedimentary deposits is the main source of phosphorus on earth. Over $75 \%$ of phosphate rock is surface mined with the remaining recovered by underground mining. Most of this rock phosphate $(80 \%)$ is used as a raw material in the manufacture of agricultural fertilizer which supplements $\mathrm{P}$ for all crops. Therefore 
conventional agriculture is dependent on mined phosphate. Phosphate rock is a limited, non-renewable, and non-substitutable resource. Rock phosphate production is already facing a decline around the world as half of the $\mathrm{P}$ deposits on earth likely to get over in coming 60-80 years (Amanullah et al. 2010; Vance 2001). Hence it becomes important to look out for other sources of phosphorus for fertilizing our agricultural fields through sustainable development for the prolonged time. Phosphorus recycling is also of significant importance. The agricultural soil of Goa, India is deficient in phosphorus and magnesium. Therefore the Government of Goa, India is assisting farmers with $50 \%$ subsidy on use of fertilizers containing above two elements (Government of Goa 2013).

Struvite is a crystalline mineral substance containing equimolar amount $(1: 1: 1)$ of magnesium ammonium and phosphate ions $\left(\mathrm{MgNH}_{4} \mathrm{PO}_{4} \cdot 6 \mathrm{H}_{2} \mathrm{O}\right)$ and is a good source of phosphorus. Apart from being a problem in sewage treatment plants (Doyle and Parsons 2002), struvite has great potential to be used as phosphate fertilizer. It can be used as slow-release fertilizer. Studies have shown that it can be equivalent or superior to other commercial phosphate fertilizers in agriculture (Ryu et al. 2012; Ghosh et al. 1996). Precipitation occurs only when the concentrations of above three ions in wastewater exceed the struvite solubility limit $(>0.2 \mathrm{~g} / \mathrm{L})$ also called as supersaturation (Barak and Stafford 2006). Another condition for struvite formation is a $\mathrm{pH}$ has to be between 8.5-9.5 (Perera et al. 2007; Uysal et al. 2010). However selective removal of phosphorus in the form other than struvite is possible also at medium $\mathrm{pH}$ (Raj et al. 2013). reports have shown that phosphorous recovery Struvite precipitation methods are very promising and likewise successful on large scale (Miles and Ellis 2001; Pastor et al. 2008; Etter et al. 2011; Song et al. 2011) although the sources of the magnesium used are diverse and expensive (Burns and Moody 2002; Huang et al. 2010). Inexpensive sources of magnesium such as $\mathrm{MgO}$-containing by-products (Quintana et al. 2005), seawater (Kumashiro et al. 2001), brine (Lee et al. 2003), magnesite (Gunay et al. 2008) and wood ash (Sakthivel et al. 2011) have also been used in some cases. Recovery of phosphorus in other form such as calcium phosphate and aluminum phosphate has also been tried using lime as a source of calcium (Banu et al. 2009) and alum (Do et al. 2013) as a source of aluminium respectively.

There are large amounts of phosphate available in waste streams from which struvite crystallization has been tried e.g. agriculture, sewage treatment effluent (Booker et al. 1999), industrial side streams such as semiconductor wastewater (Ryu et al. 2008), aerobically and anaerobically treated wastewater (Miles and Ellis 2001; Shu et al. 2006), landfill leachate (Di Iaconi et al. 2010), human urine (Booker et al. 1999; Tilley et al. 2008; Ganrot et al. 2007), and animal wastewater (Burns and Moody 2002; Yetilmezsoy and Sapci-Zengin 2009, Rahman et al. 2011; Suzuki et al. 2005).

In this study we crystallized struvite in an economical way from cow urine. Brine was used as cheap source of magnesium. Furthermore the fertilizer potential of produced struvite was evaluated.

The chemical analysis of cow urine reveals that it is rich in organic molecules and minerals that has potential as fertilizer (Krishnamurthi et al. 2004) but becomes one of the nutrient sources for eutrophication when used in excess. Urine is often promoted as a liquid fertilizer but has many drawbacks (Tilley et al. 2009). Studies have shown that direct application of urine into the crop soil decreases the nitrogen fixing capacity of the soil (Di et al. 2002; Saunders 1982). Also when manure slurries are applied to the cropland to fulfill nitrogen requirement, phosphorus become over applied as its content is much higher in the manure than the crops need (Burns and Moody 2002). Hence it becomes important that these minerals are removed by some means so that the nutrient does not become an excess when urine is applied to the cropland. Struvite has been previously precipitated from anaerobically digested cow manure (Zeng and Li 2006), but it seems to be more efficient to separate cow urine from dung. Cow urine can be used to make struvite and dung can be used for anaerobic digestion to generate biogas.

The method imposes benefits such as phosphorus and nitrogen recovery thereby cutting on eutrophication. It aims at providing insight into struvite precipitation as a method to sustainably remove phosphorus from cow urine. The struvite which is obtained can be used where there is need of phosphorus and nitrogen for the cropland. Also the leftover supernatant after making struvite (having lesser phosphorus and ammonium) can be used to make ammonium sulphate (Antonini et al. 2011) or can directly be applied in local fields in required quantities.

\section{Materials and methods}

Screening of different substrates containing phosphates

The different substrates that were screened are (1) supernatant from the effluent of food waste based anaerobic digester after centrifugation at $3,000 \mathrm{rpm}$ for $10 \mathrm{~min}$ to remove solid suspended particles. (2) Wastewater collected from an outlet of fluidized bed reactor (FBR) treating community sewage. (3) Wastewater from dairy industry. (4) Urine collected directly from Indian dairy cows during excretion using a polyethylene bucket and avoiding any contact with the floor of the cowshed. All the samples were immediately transported to the laboratory in clean 
polypropylene bottles. In all samples total ammonia nitrogen $\mathrm{pH}$, and total phosphorus for were analyzed in accordance with APHA standard methods (APHA 1995).

\section{Collection of brine and its analysis}

Salt pan is a good source of brine. It was collected from the crystallization pond of the saltern once the sodium chloride is precipitated out. Brine was collected from the crystallization pond of salt pans from Siridao Goa, India. This brine was analyzed for the $\mathrm{pH}$, conductivity and magnesium concentration. Total ammonia nitrogen and total phosphorus were also analyzed by APHA standard methods.

\section{Precipitation of struvite and optimization of its formation}

Cow urine $(\mathrm{pH} 9)$ and brine were mixed at different proportions $(1: 0.25,1: 0.5,1: 0.75,1: 1,1: 1.5$, and 1:2) in different flasks to find out the optimum struvite formation without change in the $\mathrm{pH}$. After adding brine to the urine, the $\mathrm{pH}$ of the mixture was noted. In another set of above experiment, after addition of cow urine and brine in different ratio, the final $\mathrm{pH}$ was adjusted to 9 using $5 \mathrm{~N} \mathrm{NaOH}$ solution and then kept on a magnetic stirrer. In one more set, pure magnesium chloride hexahydrate was added in stoichiometric ratio. After stirring for $10 \mathrm{~min}$, the flasks were kept for struvite crystallization. Within $2 \mathrm{~h}$ white color precipitate was formed and settled down. This was then filtered using blotting paper and dried in the shade at room temperature till all the moisture was evaporated. After drying, the amount of struvite formed was calculated. The whole process was carried out at room temperature $\left(30 \pm 2{ }^{\circ} \mathrm{C}\right)$. The dry precipitate was further used for characterization.

\section{Characterization}

$X$-ray diffraction $(X R D)$ analysis Precipitates formed under different conditions were grinded to powder using mortar and pestle. Room temperature X-ray diffraction spectra of these powder were recorded with a powder X-ray diffractometer (Mini Flex II, Rigaku, Japan) with $\mathrm{Cu} \mathrm{K} \alpha$ $(\lambda=0.15405 \mathrm{~nm})$ radiation. The quality of the struvite obtained from different conditions was compared using the XRD patterns with that of the standard struvite XRD pattern from the International Centre for Diffraction Data (ICDD). The conditions that produced quality struvite were used to make struvite in bulk from $3 \mathrm{~L}$ of cow urine.

Thermogravimetric and differential thermal analysis $(T G-D T A)$ Thermal decomposition studies of struvite were carried out on the struvite using a DTG-60 and a DTA-60 (Shimadzu, Japan) respectively. The experiments were conducted under zero air flow atmosphere $\left(50 \mathrm{~cm}^{3} / \mathrm{min}\right)$.
The sample was heated in an open platinum crucible at a rate of $1.0{ }^{\circ} \mathrm{C} / \mathrm{min}$ from $30{ }^{\circ} \mathrm{C}$ up to $300{ }^{\circ} \mathrm{C}$.

Scanning electron microscopy and energy dispersive spectroscopy (SEM-EDAX) SEM-EDAX analysis was also performed on the powdered struvite crystals for shape, morphology and individual elemental composition in selected area using SEM (JEOL, JSM-6390) equipped with EDAX (INSTA FET, Oxford instruments) operated at $20 \mathrm{keV}$. The sample powders were deposited on a carbon tape before mounting on a sample holder and gold coated for EDAX.

Fourier transform infrared spectroscopy FTIR analysis IR spectra were recorded on Shimadzu FT-IR, Prestige-21 spectrophotometer. To obtain the spectra $1 \%$ crystallized struvite was mixed and ground with $99 \% \mathrm{KBr}$. Tablets of $10 \mathrm{~mm}$ diameter were prepared by pressing the powder mixture at a load of 5 tons for $2 \mathrm{~min}$. The spectrum was taken in the range of $400-4,000 \mathrm{~cm}^{-1}$ with $4 \mathrm{~cm}^{-1}$ resolution.

\section{Evaluation of fertilizer potential of struvite}

The effect of struvite on the growth of Vigna radiata (green gram or mung bean) was tested. The comparison was made with that of commercial fertilizers such as diammonium phosphate (DAP) (Jai Kisan Samrat, Zuari Industries Ltd. Zuarinagar, Goa, India) and organic manure (Stanes Dos, Stanes and company, Coimbatore, India), composition given in Table 1. Garden soil was collected from a local supplier and dried at room temperature for 15 days. It was analyzed for $\mathrm{pH}$, total nitrogen and total phosphorus.

Seven sets of three pots (total 21 polypropylene pots) were prepared. Each pot had $8 \mathrm{~cm}$ surface diameter and $8 \mathrm{~cm}$ working depth. Two hundred grams of soil was taken, mixed thoroughly with the respective fertilizer and added to each pot. Three pots were used for each fertilizer. DAP fertilizer and organic manure was added at the rate of

Table 1 Composition of commercial fertilizers used in the plant growth test

\begin{tabular}{llll}
\hline Elements & \multicolumn{2}{l}{ Nutrient source } & Unit \\
\cline { 2 - 3 } & DAP fertilizer & Organic manure & \\
\hline $\mathrm{N}$ & 18 & 1.25 & $\%$ \\
$\mathrm{P}_{2} \mathrm{O}_{5}$ & 46 & 0.58 & \\
$\mathrm{~K}_{2} \mathrm{O}$ & 0.0 & 0.81 & \\
$\mathrm{Ca}$ & - & 1.75 & \\
$\mathrm{Mg}$ & - & 0.27 & \\
$\mathrm{Mn}$ & - & 175 & \\
$\mathrm{Zn}$ & - & 150 & \\
$\mathrm{Fe}$ & - & 1,200 & \\
$\mathrm{Cu}$ & - & 25 & \\
\hline
\end{tabular}


$110 \mathrm{kgN} / \mathrm{ha}(0.125$ and $1.25 \mathrm{~g}$ respectively). Struvite was added in various concentrations ( $\mathrm{S} 1, \mathrm{~S} 2, \mathrm{~S} 3$ and $\mathrm{S} 4$ corresponding to $0.8,1.2,1.6$ and $2 \mathrm{~g} / \mathrm{kg}$ respectively). Ten healthy seeds of $V$. radiata were sowed within the top $1 \mathrm{~cm}$ depth of soil in each pot. $40 \mathrm{ml}$ of distilled water was added to each pot. One set of three pots was used as control in which no fertilizer source was added.

The experiment was carried out at room temperature of about $30{ }^{\circ} \mathrm{C}$. All the pots were kept in the direct sunlight (D/N 12/12 h). Twenty milliliters of distilled water was added to each pot every alternate day. The germination rate was determined on day three. The length of the leaves was determined periodically in each pot. At the end of day 30, survival percentage, leaf area and total chlorophyll were determined. All the plantlets from each pot were carefully removed from the soil and washed several times with distilled water to remove all the soil particles. These were then studied for length, wet and dry weight. The dried shoots and the roots were made into powder using mortar and pestle and were used to determine total phosphorus and total nitrogen for the shoots as well as for the roots.

\section{Results and discussion}

Composition of different waste collected, is given Table 2. The freshly collected cow urine had a $\mathrm{pH}$ of 6.5 . The phosphorus concentration was as high as $305 \mathrm{mg} / \mathrm{L}$. Total ammonia nitrogen content was $105 \mathrm{mg} / \mathrm{L}$, and after maturation $(\mathrm{pH} 9)$ it reached to $7,732.3 \mathrm{mg} / \mathrm{L}$. Chemical composition of cow urine depends on feeding habits, physical activities, body size and climate of resident location. The brine had a $\mathrm{pH}$ of 7 , ammonia nitrogen was below detection, salinity was 445 parts per thousand and density was $4.26 \mathrm{~g} / \mathrm{L}$. Magnesium ions were found in a concentration of $18.53 \mathrm{~g} / \mathrm{L}$. Total P (mg/L) was highest in cow urine, 305; followed by dairy effluent, 262; effluent from food waste based anaerobic digester, 194; rice wash water, 105; and
Table 2 Chemical analysis of different samples used for struvite formation

$N D$ not determined

Fig. $1 \mathrm{pH}$ variation in the cow urine when stored at room temperature

\begin{tabular}{|c|c|c|c|c|c|c|c|c|}
\hline $\begin{array}{l}\text { Sr. } \\
\text { no }\end{array}$ & Sample & $\mathrm{pH}$ & $\begin{array}{l}\text { Total } \\
\text { P (mg/ } \\
\text { L) }\end{array}$ & $\begin{array}{l}\text { Total } \\
\mathrm{NH}_{3}-\mathrm{N} \\
(\mathrm{mg} / \mathrm{L})\end{array}$ & $\begin{array}{l}\text { Magnesium } \\
(\mathrm{g} / \mathrm{L})\end{array}$ & $\begin{array}{l}\text { Salinity at } \\
20{ }^{\circ} \mathrm{C} \\
(\% \mathrm{o})\end{array}$ & $\begin{array}{l}\text { Density } \\
(d \text { 20/20) } \\
\mathrm{g} / \mathrm{L}\end{array}$ & $\begin{array}{l}\text { Conductivity } \\
(\mathrm{ms} / \mathrm{cm})\end{array}$ \\
\hline 1 & $\begin{array}{l}\text { Effluent from } \\
\text { anaerobic } \\
\text { digester }\end{array}$ & 7 & 194 & 1,043 & ND & ND & ND & ND \\
\hline 2 & Wastewater & 7 & 50 & 17.92 & ND & ND & ND & ND \\
\hline 3 & $\begin{array}{l}\text { Rice wash } \\
\text { water }\end{array}$ & 6.5 & 105 & ND & ND & ND & ND & ND \\
\hline 4 & Dairy effluent & 6 & 262 & ND & ND & ND & ND & ND \\
\hline 5 & $\begin{array}{l}\text { Fresh cow } \\
\text { urine }\end{array}$ & 6.5 & 305 & 105 & ND & ND & ND & ND \\
\hline 6 & Brine & 7 & 0.04 & 0 & 18.53 & 445 & 4.268 & 101 \\
\hline 7 & $\begin{array}{l}\text { Matured cow } \\
\text { urine }\end{array}$ & 9 & 305 & $7,732.3$ & ND & ND & ND & ND \\
\hline
\end{tabular}




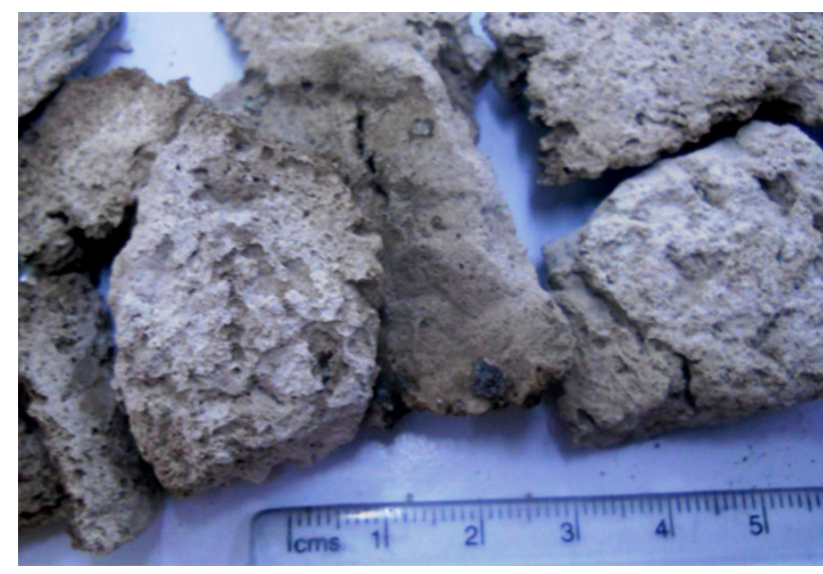

Fig. 2 Image of precipitated dried struvite taken with Nikon COOLPIX L21 digital camera

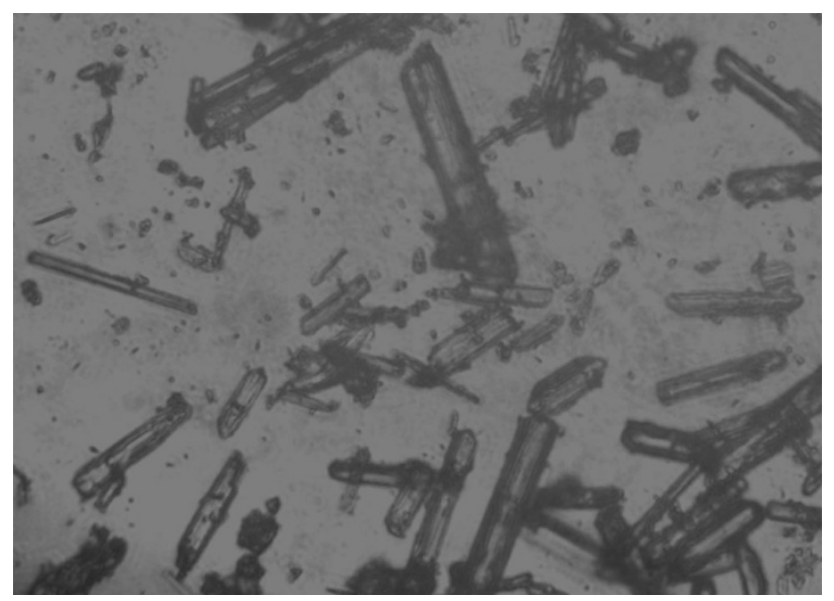

Fig. 3 Struvite crystals as seen in $\times 40$ of Nikon Eclipse TS100 phase contrast microscope. Image captured with Nikon COOLPIX L21 digital camera

sewage wastewater, 50. Decision was made to use cow urine to make struvite as it contained high concentration of phosphate and was relatively free of large suspended particles. Urine was stored at room temperature and was monitored everyday for increase in the pH up to 9 (Fig. 1).

When dried at room temperature the precipitated struvite turned into appearance of small rocky blocks (Fig. 2). This was scrapped using a needle and the particles when seen under the phase contrast microscope appeared to be as rod shaped structures (Fig. 3).

Characterization of the formed precipitate

\section{XRD studies}

Powder XRD analysis of room temperature dried struvite which was crystallized using pure magnesium chloride hexahydrate showed best results, followed by struvite
Table 3 Struvite production from cow urine using brine at different ratios of mixing

\begin{tabular}{lllll}
\hline Sr no. & Urine $(\mathrm{ml})$ & Brine $(\mathrm{ml})$ & Weight of precipitate $(\mathrm{g})$ & $\mathrm{pH}$ \\
\hline 1 & 50 & 12.5 & 2.40 & 9 \\
2 & 50 & 25 & 4.28 & 9 \\
3 & 50 & 37.5 & 4.16 & 9 \\
4 & 50 & 50 & 3.23 & 8.85 \\
5 & 50 & 62.5 & 3.01 & 8.6 \\
6 & 50 & 75 & 2.29 & 8.5 \\
7 & 50 & 87.5 & 2.14 & 7.5 \\
8 & 50 & 100 & 2.15 & 7.5 \\
\hline
\end{tabular}

crystallized using ratio 1:0.5 of cow urine to brine mixture. (Table 3); (Fig. 4) when compared to the peaks of synthetic struvite ICDD card no. 15-0762. It showed the orthorhombic crystal structure arrangement. The slight difference in the XRD spectra may be attributed to the trace amount of impurities present in the struvite precipitate. As the ratio decreased, the amount as well as the quality of struvite formed decreased. Also the $\mathrm{pH}$ decreases at lower ratios. The quality struvite was not obtained in lower ratios even after adjusting the $\mathrm{pH}$ to 9 as can be seen from Fig. 4 and Table 4. This may be due to the ion concentration present below supersaturation level due to dilution factor.

\section{TG-DTA studies}

Drying of struvite precipitate is an important step in maintaining its crystal structure size and fragility. The loss in this is dependent upon the temperature and the rate of heating. Previous studies (Frost et al. 2004) have shown the loss of mass of struvite takes place at 39.5, 57.8 and $82.6{ }^{\circ} \mathrm{C}$ resulting in decomposition of struvite crystals. In our thermal decomposition experiment on struvite crystals made using brine (Fig. 5), loss of mass was observed at 40.24 and $83.45{ }^{\circ} \mathrm{C}$ (closely resembling the previous data) with total loss in 23 and $33 \%$ respectively of original weight. Furthermore a loss of mass was observed at $214.92{ }^{\circ} \mathrm{C}$ with total loss in $53 \%$ of original weight. No further loss in mass was observed till $300{ }^{\circ} \mathrm{C}$. This indicates that major loss in weight occurs between 39.5 and $83.45^{\circ} \mathrm{C}$ and struvite starts dehydrating and loses its structure at $40{ }^{\circ} \mathrm{C}$ and above. Earlier studies have shown that $\mathrm{P}$ release from environmental sample like sludge increased with increase in temperature and is maximum at $60{ }^{\circ} \mathrm{C}$ for $3 \mathrm{~h}$, (Raj et al. 2012) but degradation of the released $\mathrm{P}$ takes place above this temperature. Effect of temperature on crystallization of struvite from cow urine can be studied in similar way. But release of ammonia from the sample is expected at higher temperatures above $40{ }^{\circ} \mathrm{C}$. 


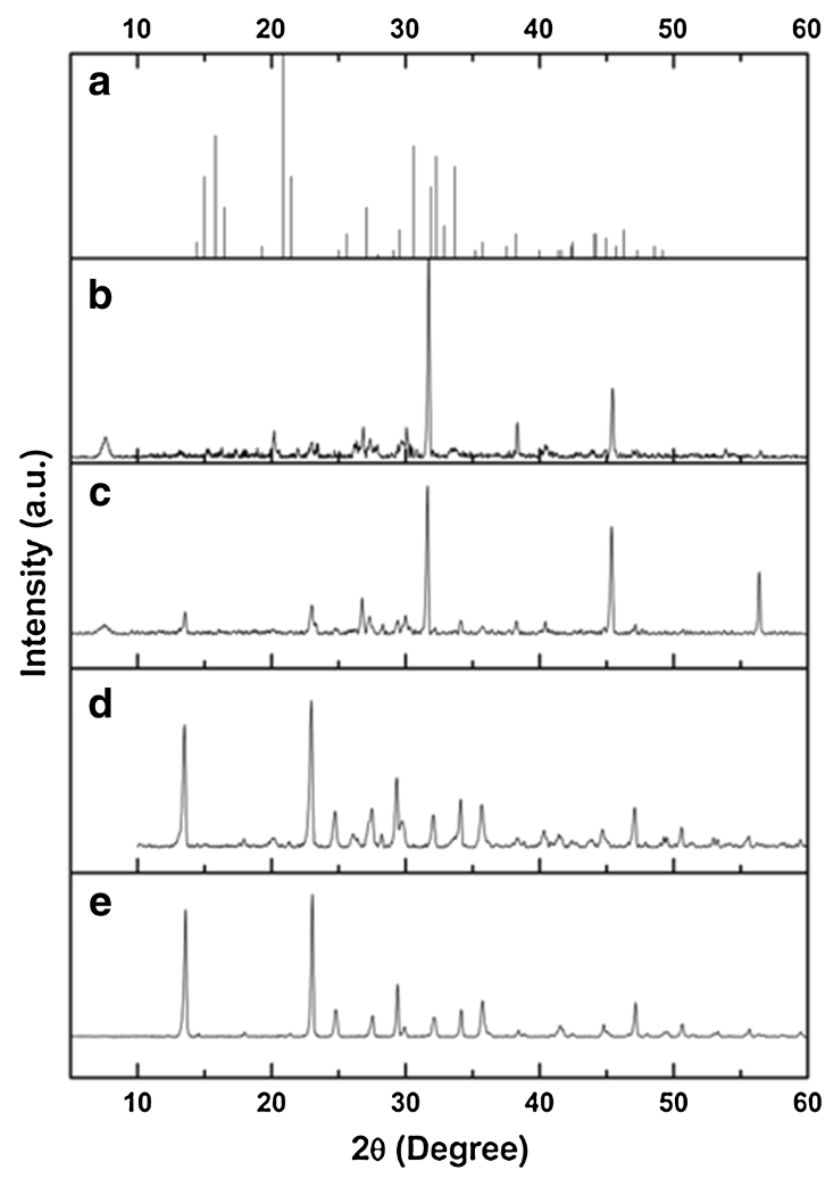

Fig. 4 Powder XRD pattern for the precipitated product obtained from cow urine a standard struvite ICDD Card No. 15-0762 b Mixing ratio $1: 2, \mathrm{pH} 7$ c Mixing ratio $1: 2$ at $\mathrm{pH}$ adjusted to 9.0 using $1 \mathrm{~N}$ $\mathrm{NaOH}$, and d Mixing ratio 1:0.5, $\mathrm{pH} 9.0$ e using $\mathrm{MgCl}_{2}$

Table 4 Struvite production from cow urine using brine at different ratios and at $\mathrm{pH} 9$

\begin{tabular}{llll}
\hline Sr no. & Urine $(\mathrm{ml})$ & Brine $(\mathrm{ml})$ & Weight of precipitate $(\mathrm{g})$ \\
\hline 1 & 50 & 12.5 & 2.40 \\
2 & 50 & 25 & 4.28 \\
3 & 50 & 37.5 & 4.16 \\
4 & 50 & 50 & 5.17 \\
5 & 50 & 62.5 & 7.12 \\
6 & 50 & 75 & 5.96 \\
7 & 50 & 87.5 & 8.84 \\
8 & 50 & 100 & 9.23 \\
\hline
\end{tabular}

\section{FT-IR studies}

FTIR absorption spectra are shown in Fig. 6 for struvite crystallized using brine as well as $\mathrm{MgCl}_{2}$. There is no difference in the absorption pattern of both except the peak intensities are lower for the struvite crystallized using brine than that of struvite crystallized using $\mathrm{MgCl}_{2}$. An

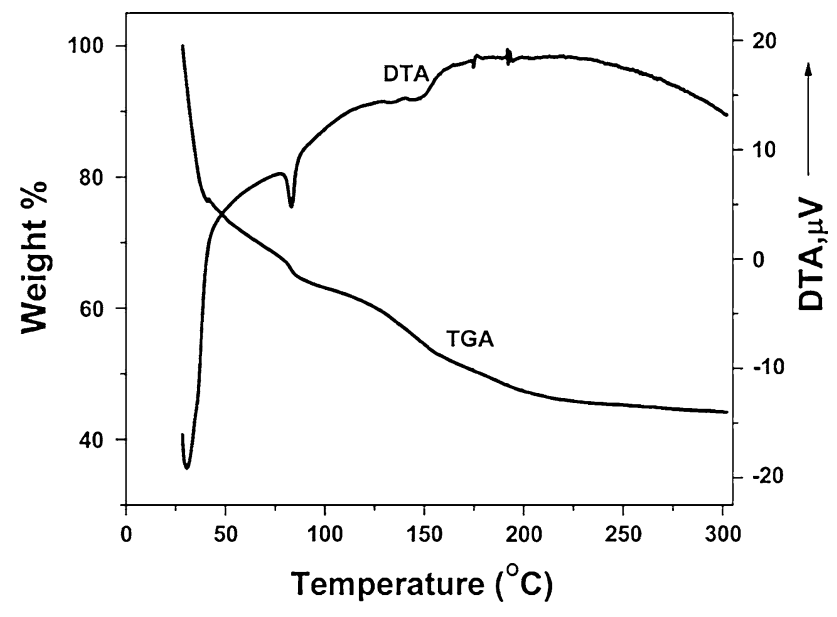

Fig. 5 TGA and DTA curve of struvite crystallized using brine

absorption peak centered at $3,558 \mathrm{~cm}^{-1}$ is due to the $\mathrm{N}-\mathrm{H}$ stretching. The strong and broad peak in the range between 3,500 and $2,750 \mathrm{~cm}^{-1}$ is due to the $\mathrm{O}-\mathrm{H}$ stretching vibration motion, a characteristic of water of hydration. The weak bands seen between 2,600 and $2,100 \mathrm{~cm}^{-1}$ are mostly due to water phosphate hydrogen bonding. The weak and broad peak at $1,641 \mathrm{~cm}^{-1}$ is due to the $\mathrm{H}-\mathrm{N}-\mathrm{H}$ or $\mathrm{H}-\mathrm{O}-\mathrm{H}$ scissoring effect. Peaks centered at 1,527 and $1,400 \mathrm{~cm}^{-1}$ can be attributed to the $\mathrm{N}-\mathrm{H}$ bending vibrations. The splitting of the peak may be due to the rotation of the ammonium ions. A low intensity but sharp peak is seen in both cases centered at $1,099 \mathrm{~cm}^{-1}$ is mainly due to the ionic phosphate (Fig. 7). Another sharp medium intensity peak centered at $846 \mathrm{~cm}^{-1}$ is due to the rocking of $\mathrm{N}-\mathrm{H}$ bond. Weak peaks at 671 and $474 \mathrm{~cm}^{-1}$ are due to the metal-oxygen bond. Thus it is clear from FT-IR that there is presence of water of hydration, $\mathrm{N}-\mathrm{H}$ bond $\mathrm{NH}_{4}{ }^{+}$ ion $\mathrm{PO}_{4}{ }^{-}$ion $\mathrm{P}-\mathrm{O}$ bond and metal-oxygen bond.

\section{SEM-EDAX}

SEM images were taken for the powered struvite which showed the presence of irregular granular shaped particles (Figs. 8, 9). EDAX showed the composition of individual elemental composition in atomic\% for both kind of crystallized struvite (Figs. 10, 11). The results are compiled in Table 5. Struvite crystallized using magnesium chloride showed P $2.31 \%, \mathrm{Mg} 11.47 \%$ and N $3.35 \%$. Whereas struvite crystallized using brine showed $\mathrm{P} 2.31 \%, \mathrm{Mg}$ $16.72 \%$ and N $2.35 \%$. The chlorine ion content was 11.32 and $19.34 \%$ in struvite crystallized with magnesium chloride and brine respectively. This indicates that magnesium chloride may still present in struvite. Struvite crystallized from brine also contained sodium ion ( $\mathrm{Na})$ $9.17 \%$ and potassium ion (K) $0.59 \%$ for the obvious 
Fig. 6 FT-IR of struvite crystallized using brine (curve a) and using $\mathrm{MgCl}_{2}$ (curve b)
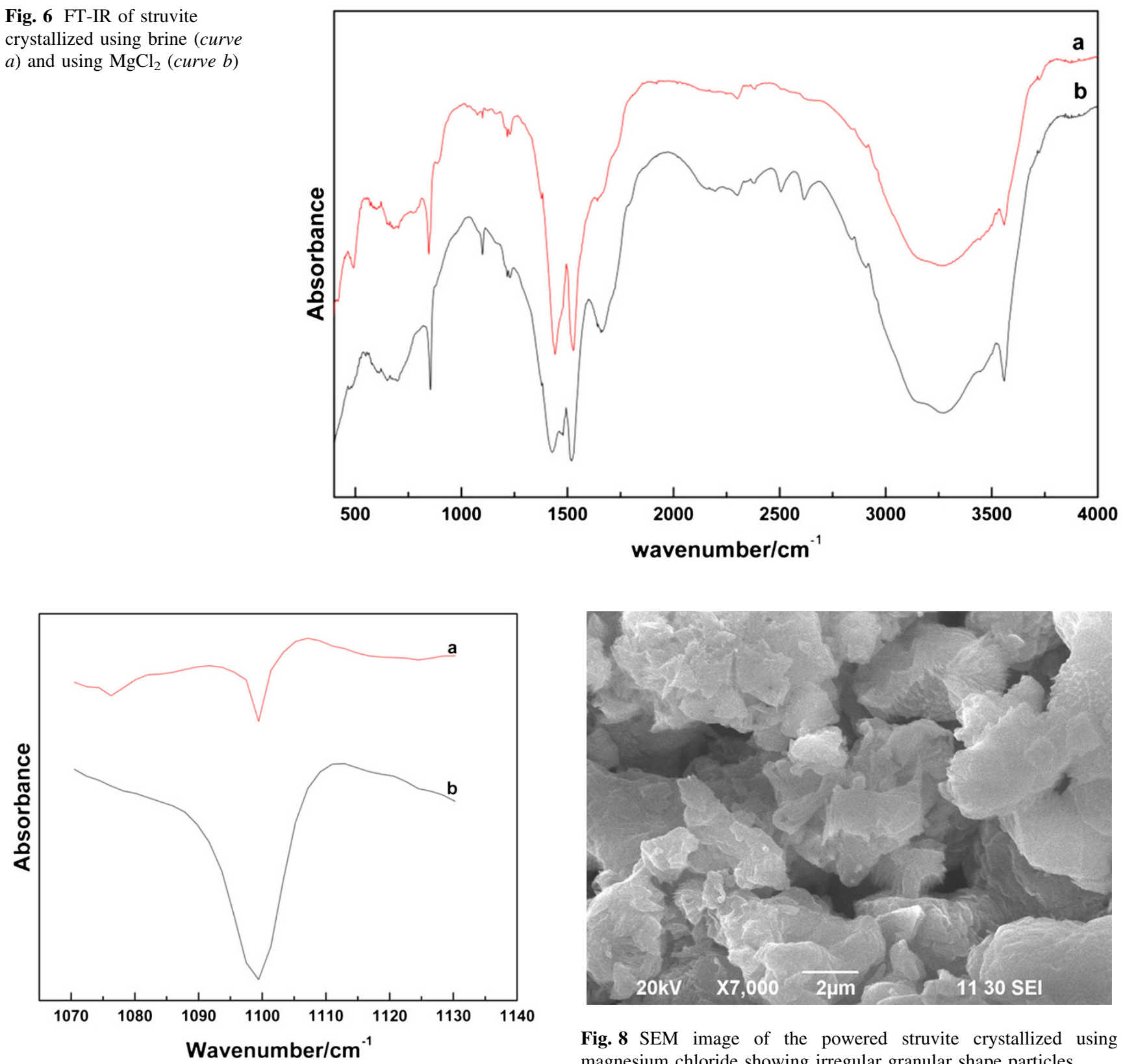

Fig. 7 Sharp peak in FT-IR absorbance of struvite crystallized using brine (curve $a$ ) and using $\mathrm{MgCl}_{2}$ (curve $b$ ) centered at $1,099 \mathrm{~cm}^{-1}$

reason that the brine contains these ions in the form of $\mathrm{NaCl}$ and $\mathrm{KCl}$ and got precipitated along with the struvite. This indicates that struvite crystallized using brine contains impurities such as $\mathrm{NaCl}$ and $\mathrm{KCl}$ in small quantities. In both the cases sulfur was also present which must have originated from the cow urine itself. When to be considered as NPK fertilizer, struvite crystallized using magnesium chloride has a ratio of 10:9:0 and struvite crystallized using brine has ratio of 10:7.8:1.7. Struvite crystallized by Ryu et al. (2012), has elemental NPK ratio of 10:4.2:2.9 and can be used as fertilizer. Since magnesium is deficient in soil

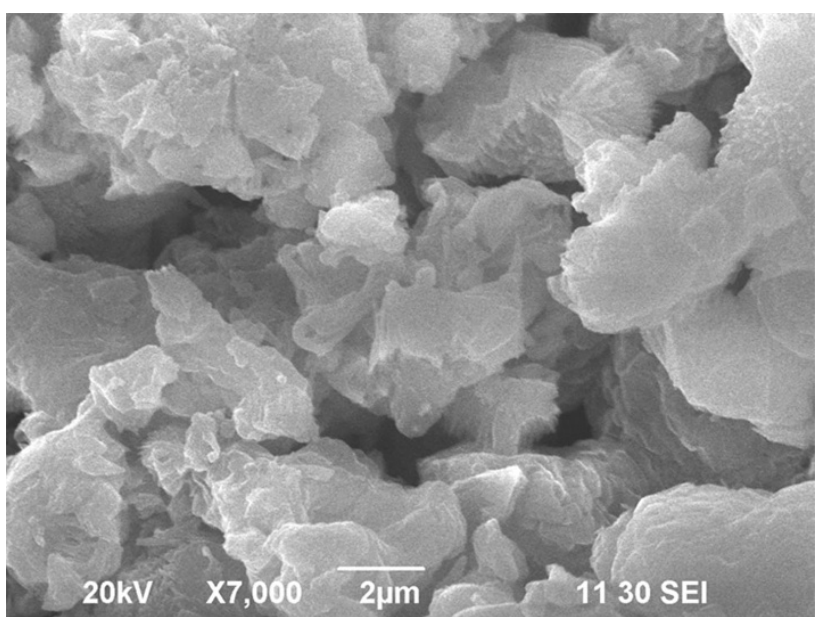

Fig. 8 SEM image of the powered struvite crystallized using magnesium chloride showing irregular granular shape particles

such as soil in Goa, use of struvite adds an advantage as farmer need not add magnesium fertilizer separately.

The analysis of struvite as per APHA standard methods for phosphate, magnesium and ammonium ions showed $5.85,3.16$, and $0.56 \%$ respectively [theoretical values for each of them are 12.6, 9.9 and $5.7 \%$ respectively (Sakthivel et al. 2011)].

\section{Fertility evaluation of precipitated struvite}

The obtained struvite was utilized in cultivation of $V$. radiata at different dosage and compared with that of commercial fertilizers to assess its fertility. During the 


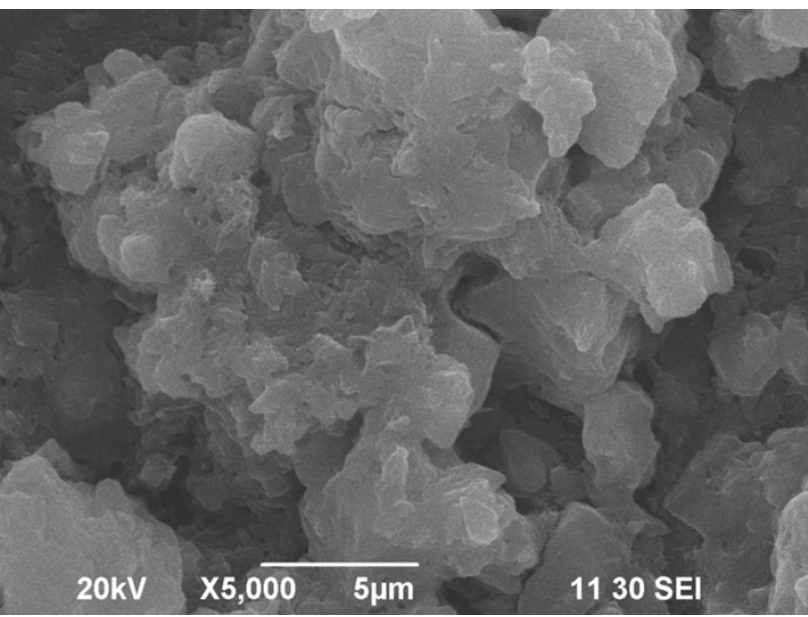

Fig. 9 SEM image of the powered struvite crystallized using brine

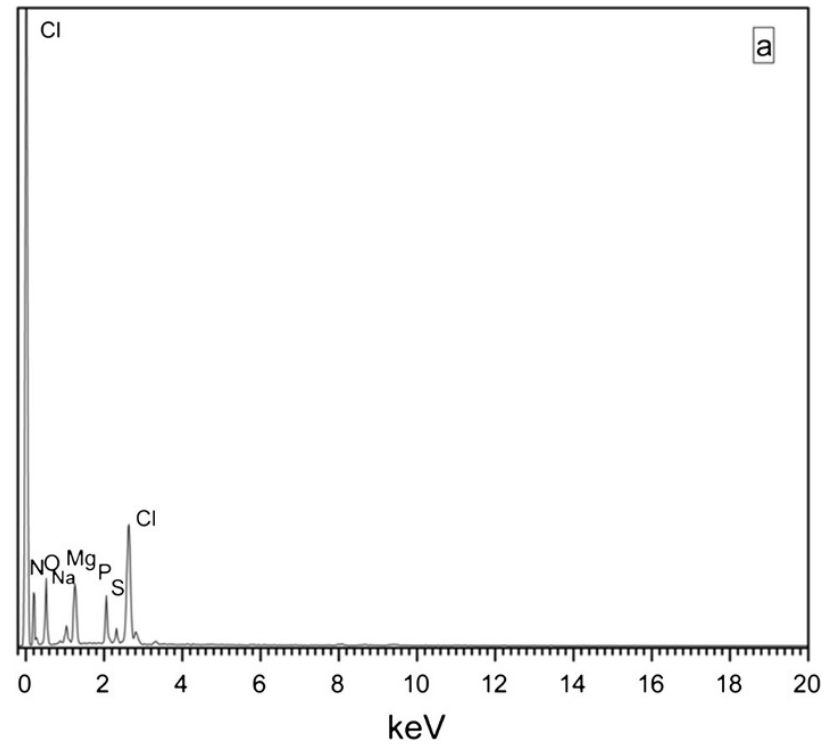

Fig. 10 EDAX of the powdered struvite crystallized using magnesium chloride

experimental period, the tallest leaf in each pot was selected and measured for its length. The tests showed that the $V$. radiata grew at different rates depending on the dosage of struvite and fertilizers as illustrated in Fig. 12. V. radiata in the struvite pots showed the highest growth rate. The best growth rate was observed in the pots where $2 \mathrm{~g} / \mathrm{kg}$ (S4) of soil struvite was added.

Vigna radiata seeds inoculated with 1.6 and $2.0 \mathrm{~g} / \mathrm{kg}$ of struvite showed a significant increase in $\%$ germination compared to control by 10 and $3.34 \%$ (Table 6). Also the total survival at the end of day 30 was $100 \%$ in $2.0 \mathrm{~g} / \mathrm{kg}$ of struvite compared to control.

The average leaf length of $V$. radiata in DAP, organic, $\mathrm{S} 1, \mathrm{~S} 2, \mathrm{~S} 3, \mathrm{~S} 4$ and control pots reached 3.8, 4.5, 4.0,

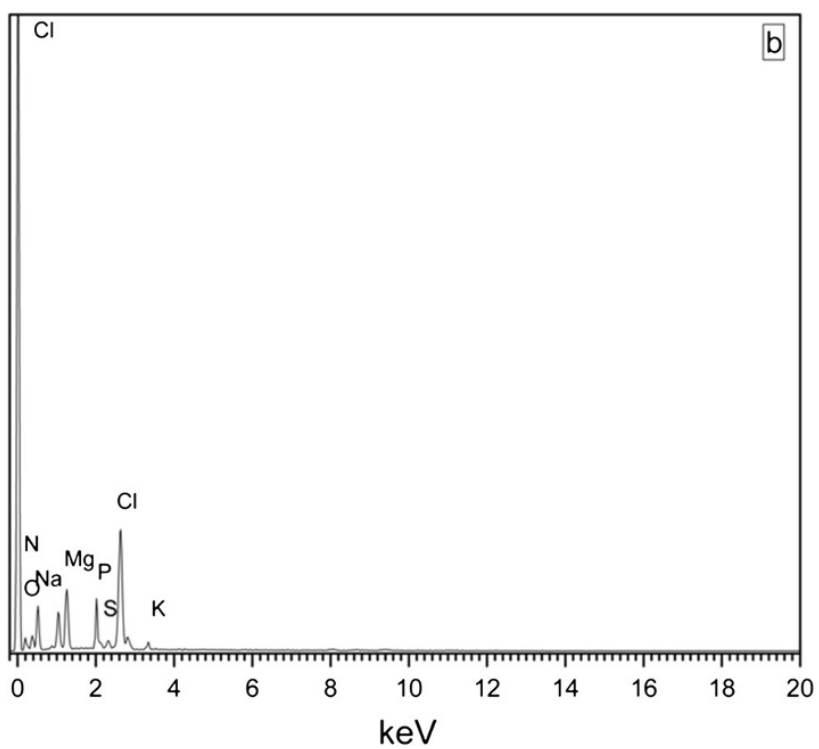

Fig. 11 EDAX of the powdered struvite crystallized using brine

Table 5 EDAX analysis of powdered struvite crystallized using magnesium chloride and brine

\begin{tabular}{lcc}
\hline Element & With $\mathrm{MgCl} \cdot 6 \mathrm{H}_{2} \mathrm{O}(\mathrm{atm} \%)$ & With brine $(\mathrm{atm} \%)$ \\
\hline $\mathrm{N}$ & 3.35 & 3.35 \\
$\mathrm{O}$ & 62.58 & 52.74 \\
$\mathrm{Na}$ & 1.37 & 9.17 \\
$\mathrm{Mg}$ & 16.72 & 11.47 \\
$\mathrm{P}$ & 2.31 & 2.31 \\
$\mathrm{~S}$ & 2.35 & 1.03 \\
$\mathrm{Cl}$ & 11.32 & 19.34 \\
$\mathrm{~K}$ & - & 0.59 \\
\hline
\end{tabular}

3.7,4.9, 5.1 and $4.6 \mathrm{~cm}$ respectively, as presented in Fig. 13.

As regarding the stem and root length the increase was significantly higher than the control. The stem length decreased in order of $\mathrm{S} 4>$ organic manure $>\mathrm{S} 3>$ $\mathrm{DAP}>\mathrm{S} 2>\mathrm{S} 1>$ control. Whereas the root length decreased in order of $\mathrm{S} 4>\mathrm{S} 2>$ organic manure $>$ S3 $>$ DAP $>$ S1 > control.

Leaf area also followed the similar order of decrease, S4 $>$ organic manure $>$ S3 $>$ DAP $>$ control $>$ S1 $>$ S2 .

It is very much evident that the addition of 1.6 and $2 \mathrm{~g} / \mathrm{kg}$ struvite significantly increased the average fresh and dry weights of stem and root of $V$. radiata in comparison with the control. The average fresh weights of stems in S4 pots ranked first in the experimental group. When above ground dry weight is considered, struvite gave superior results to that of other fertilizers.

Total chlorophyll was found to be 28.96 , and $28.02 \mathrm{mg} / \mathrm{g}$ of wet weight in S4 and S3 respectively which was 

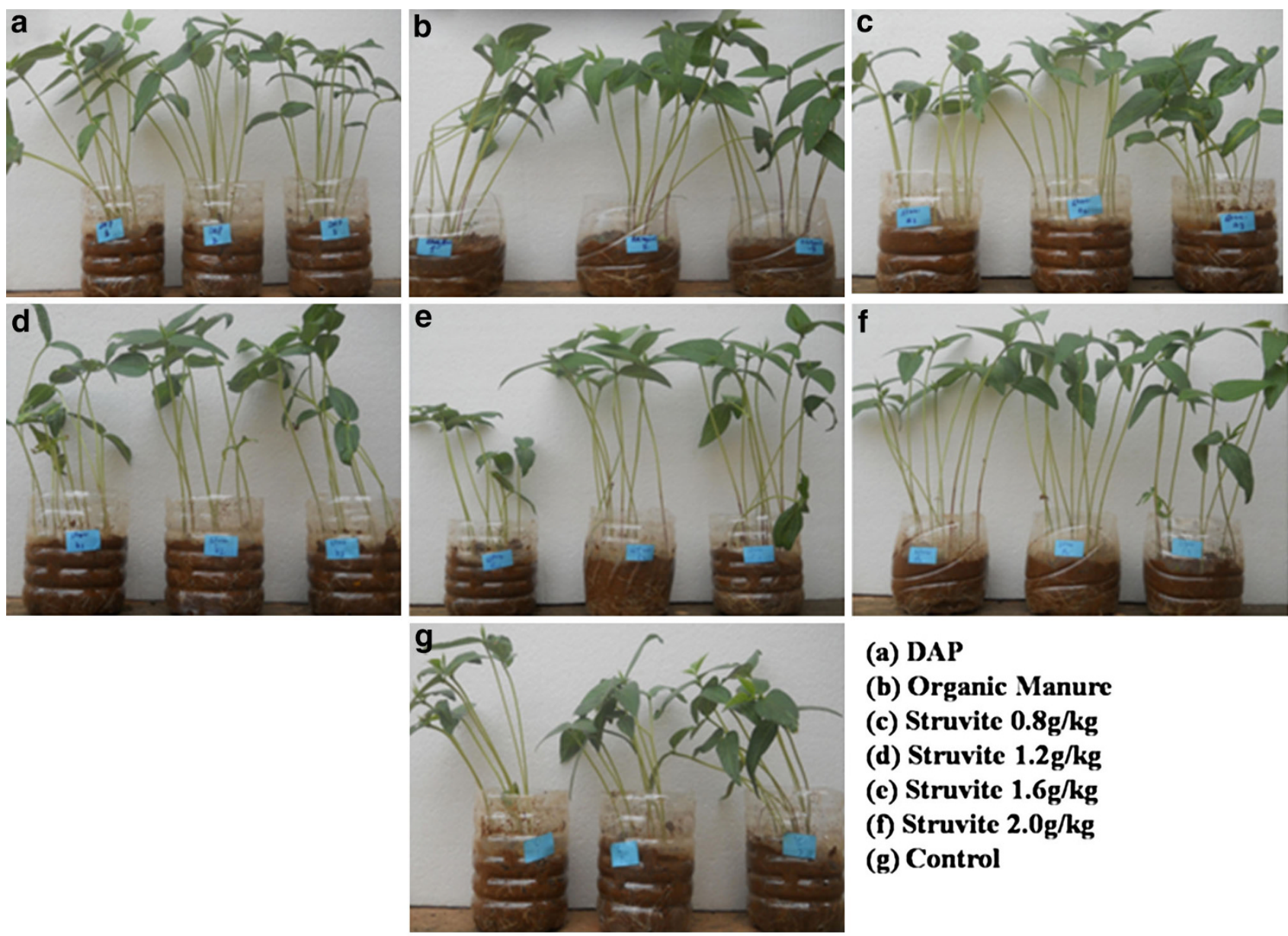
(a) DAP
(b) Organic Manure
(c) Struvite $0.8 \mathrm{~g} / \mathrm{kg}$
(d) Struvite $1.2 \mathrm{~g} / \mathrm{kg}$
(c) Struvite $1.6 \mathrm{~g} / \mathrm{kg}$
(f) Struvite $2.0 \mathrm{~g} / \mathrm{kg}$
(g) Control

Fig. 12 Vigna radiata plants showing the effect of different fertilizers on its growth at 30 days after sowing

slightly higher than that of control $27.78 \mathrm{mg} / \mathrm{g}$ of wet weight.

Total phosphorus and total nitrogen were analyzed for dried stem and root. Stem total phosphorus was found to increase in order of $\mathrm{S} 1<\mathrm{S} 2<$ control $<\mathrm{DAP}$ $<\mathrm{S} 3<$ organic $<\mathrm{S} 4$ whereas root total nitrogen was found to increase in $\mathrm{S} 3<\mathrm{S} 2<\mathrm{S} 4<\mathrm{DAP}<$ organic manure $<\mathrm{S} 1<$ control.

Total nitrogen in stems was in order of organic manure $<\mathrm{S} 4<\mathrm{S} 3<\mathrm{DAP}<\mathrm{S} 2<\mathrm{S} 1<$ control. And in root it showed the order $\mathrm{S} 4<\mathrm{S} 3<\mathrm{S} 2<$ organic manure $<$ DAP $<$ control $<$ S1.

Total struvite produced from cow urine using brine with optimum ratio was approximately $40 \mathrm{~g} / \mathrm{L}$. India's total number of dairy livestock is ranking highest in the world. In 2007 it was having a total of 199.1 and 105.3 million cattle and buffalos respectively (Government of India 2010). On average an adult dairy cow excretes about $26 \mathrm{~kg}$ urine per $1,000 \mathrm{~kg}$ body weight per day [(ASAE) 2003], which consequently becomes a major component of the livestock waste. The manure excreted from these animals ultimately finds its way into the water bodies resulting in elevation of nutrient levels within them. If struvite is made from this waste, a large amount of phosphate can be recovered. Theoretically at the yield of $40 \mathrm{~g} / \mathrm{L}$ a total of 12,176 tons struvite could be made per day all over India. Formation and optimization of struvite need to be carried out at large scale commercial level. Thorough and feasible economic evaluations need to be carried out in this regard.

Production of struvite has an additional advantage for farmer. If a farmer is having cows, he can produce his own fertilizer containing phosphate and magnesium for agriculture rather than spending money on the purchase of commercial phosphate fertilizers.

Use of brine will further give some financial assistance to the sea salt producing community by selling the brine.

Hence new, feasible and effective ways of removing elements like phosphorus and nitrogen from such discharges are always important in nutrient pollution control of the environment. 
Table 6 Analysis of plant growth experiment

\begin{tabular}{|c|c|c|c|c|c|c|c|}
\hline & \multirow[t]{2}{*}{ DAP } & \multirow{2}{*}{$\begin{array}{l}\text { Organic } \\
\text { manure }\end{array}$} & \multicolumn{4}{|l|}{ Struvite } & \multirow[t]{2}{*}{ Control } \\
\hline & & & $(0.8 \mathrm{~g} / \mathrm{kg})$ & $(1.2 \mathrm{~g} / \mathrm{kg})$ & $(1.6 \mathrm{~g} / \mathrm{kg})$ & $(2.0 \mathrm{~g} / \mathrm{kg})$ & \\
\hline Germination rate $(\%)$ & $93.33 \pm 5.77$ & $90.00 \pm 0$ & $90.00 \pm 10$ & $86.67 \pm 5.77$ & $93.33 \pm 11.54$ & $86.67 \pm 15.27$ & $83.33 \pm 15.27$ \\
\hline Total survival (\%) & $75.19 \pm 22.67$ & $92.59 \pm 6.42$ & $89.17 \pm 10.10$ & $70.37 \pm 27.96$ & $80.00 \pm 20.00$ & $100.00 \pm 0.00$ & $89.17 \pm 10.10$ \\
\hline Leaf area $\left(\mathrm{cm}^{2}\right)$ & $8.38 \pm 0.25$ & $10.43 \pm 1.94$ & $7.57 \pm 0.47$ & $7.31 \pm 0.77$ & $9.32 \pm 2.50$ & $10.90 \pm 0.390$ & $7.73 \pm 0.76$ \\
\hline Stem length $(\mathrm{cm})$ & $23.77 \pm 0.25$ & $28.23 \pm 2.25$ & $19.60 \pm 1.91$ & $19.73 \pm 3.33$ & $27.60 \pm 4.87$ & $30.33 \pm 1.17$ & $19.50 \pm 1.00$ \\
\hline Root length $(\mathrm{cm})$ & $10.83 \pm 0.76$ & $12.17 \pm 0.76$ & $12.67 \pm 2.52$ & $10.00 \pm 2.00$ & $11.67 \pm 1.53$ & $13.00 \pm 3.00$ & $8.00 \pm 1.00$ \\
\hline $\begin{array}{l}\text { Total chlorophyll (mg/ } \\
\text { g of wet wt.) }\end{array}$ & $19.58 \pm 3.28$ & $24.25 \pm 5.49$ & $15.75 \pm 5.67$ & $24.17 \pm 1.81$ & $28.02 \pm 2.68$ & $28.96 \pm 2.69$ & $27.78 \pm 3.64$ \\
\hline Stem wet wt. (g) & $4.12 \pm 1.02$ & $6.32 \pm 1.23$ & $2.25 \pm 0.87$ & $2.25 \pm 0.20$ & $5.04 \pm 1.42$ & $7.88 \pm 1.01$ & $3.30 \pm 0.86$ \\
\hline Stem dry wt. (g) & $0.90 \pm 0.16$ & $1.52 \pm 0.30$ & $0.42 \pm 0.18$ & $0.40 \pm 0.07$ & $1.18 \pm 0.46$ & $1.87 \pm 0.22$ & $0.61 \pm 0.09$ \\
\hline Root wet wt. (g) & $1.98 \pm 0.14$ & $5.25 \pm 1.44$ & $1.61 \pm 0.22$ & $0.83 \pm 0.27$ & $4.08 \pm 1.81$ & $4.06 \pm 1.80$ & $2.04 \pm 0.34$ \\
\hline Root dry wt. (g) & $0.23 \pm 0.04$ & $0.86 \pm 0.10$ & $0.29 \pm 0.14$ & $0.22 \pm 0.02$ & $0.69 \pm 0.35$ & $0.72 \pm 0.33$ & $0.25 \pm 0.06$ \\
\hline $\begin{array}{l}\text { Stem total phosphorus } \\
(\mathrm{mg} / \mathrm{kg})\end{array}$ & $44.63 \pm 10.33$ & $66.45 \pm 23.87$ & $23.82 \pm 20.48$ & $25.09 \pm 20.35$ & $36.17 \pm 2.20$ & $61.03 \pm 7.45$ & $35.13 \pm 5.21$ \\
\hline $\begin{array}{l}\text { Root total phosphorus } \\
(\mathrm{mg} / \mathrm{kg})\end{array}$ & 4.94 & $6.54 \pm 3.25$ & $7.86 \pm 0.53$ & $1.81 \pm 0.72$ & $1.44 \pm 0.54$ & $4.88 \pm 1.83$ & $17.94 \pm 5.08$ \\
\hline $\begin{array}{l}\text { Stem total nitrogen } \\
(\%)\end{array}$ & $3.50 \pm 0.14$ & $2.66 \pm 0.16$ & $4.27 \pm 0.08$ & $4.20 \pm 0.16$ & $2.94 \pm 0.29$ & $2.87 \pm 0.21$ & $4.34 \pm 0.16$ \\
\hline $\begin{array}{l}\text { Root total nitrogen } \\
(\%)\end{array}$ & $2.87 \pm 0.08$ & $2.31 \pm 0.21$ & $3.29 \pm 0.08$ & $2.31 \pm 0.08$ & $1.75 \pm 0.08$ & $1.61 \pm 0.08$ & $2.87 \pm 0.21$ \\
\hline
\end{tabular}

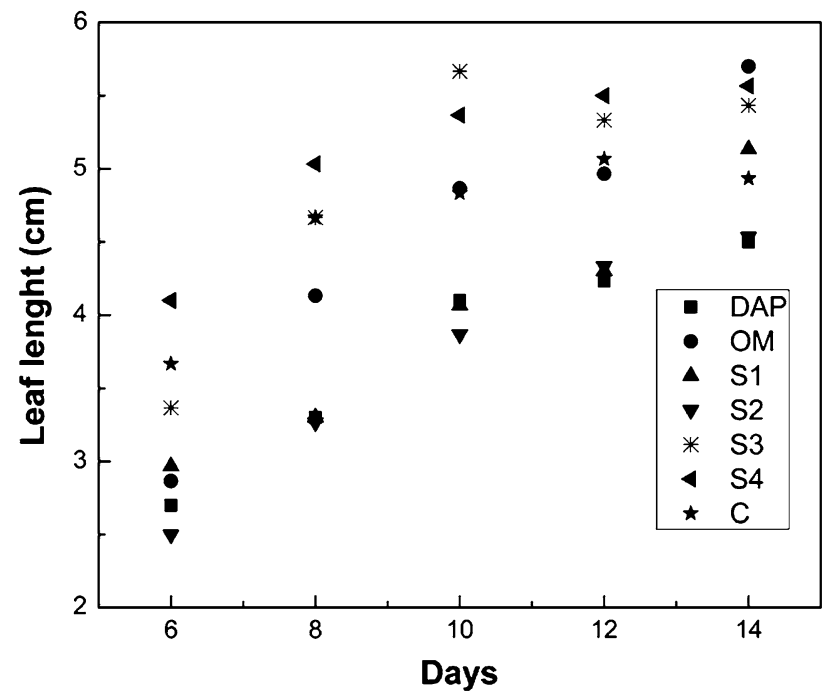

Fig. 13 Length of leaves over the time

\section{Conclusion}

Struvite is a good source of phosphate and it can be recovered from livestock waste such as cow urine. Our results indicate that 1:0.5 mixing ratio of cow urine to brine gives best quality struvite. The structure and stability of struvite is affected when dried above $40{ }^{\circ} \mathrm{C}$. The analysis of struvite for phosphate, magnesium and ammonium ions showed 5.85, 3.16, and $0.56 \%$ respectively. In the fertilizer potential study of struvite on $V$. radiata, $2.0 \mathrm{~g}$ struvite per $\mathrm{kg}$ of soil showed best plant growth, among the lower concentrations used. However more studies need to be carried out to ascertain the optimum amount of struvite required by different crops. Thus struvite can be made from a renewable source for a sustainable agricultural development.

Open Access This article is distributed under the terms of the Creative Commons Attribution License which permits any use, distribution, and reproduction in any medium, provided the original author(s) and the source are credited.

\section{References:}

Amanullah MM, Sekar S, Vincent S (2010) Plant growth substances in crop production: a review. Asian J Plant Sci 9:215-222. doi:10.3923/ajps.2010.215.222

American Society of Agricultural Engineers (ASAE) Standards (2003) Manure production and characteristics

Antonini S, Paris S, Eichert T, Clemens J (2011) Nitrogen and phosphorus recovery from human urine by struvite precipitation and air stripping in Vietnam. J Clean: Soil Air Water 39(12):1099-1104. doi:10.1002/clen.201100036

APHA (1995) Standard methods, 19th edn. American Public Health Association, Washington, DC

Banu JR, Do K-U, Yeom IT (2009) Nutrient removal in an $\mathrm{A}_{2} \mathrm{O}-\mathrm{MBR}$ reactor with sludge reduction. Bioresour Technol 100: 3820-3824. doi:10.1016/j.biortech.2008.12.054

Barak P, Stafford A (2006) Struvite: a recovered and recycled phosphorus fertilizer. In: Proceedings of the Wisconsin fertilizer, aglime and pest management conference, vol 45 
Booker NA, Priestley AJ, Fraser IH (1999) Struvite formation in wastewater treatment plants: opportunities for nutrient recovery. J Envt Tech 20:777-782. doi:10.1080/09593332008616874

Burns RT, Moody LB (2002) Phosphorus recovery from animal manures using optimized struvite precipitation. In: Proceedings of coagulants and flocculants: global market and technical opportunities for water treatment chemicals. Chicago, Illinois, 2002

Di Iaconi C, Pagano M, Ramadori R, Lopez A (2010) Nitrogen recovery from a stabilized municipal landfill leachate. J Bio Tech 101:1732-1736. doi:10.1016/j.biortech.2009.10.013

Di HJ, Cameron KC, Silva RG, Russell JM, Barnett JW (2002) A lysimeter study of the fate of ${ }^{15}-\mathrm{N}$ labelled nitrogen in cow urine with or without farm dairy effluent in a grazed dairy pasture soil under flood irrigation. N Z J Agric Res 45:235-244. doi:10.1080/ 00288233.2002 .9513514

Do K-U, Banu R, Kaliappan S, Yeom IT (2013) Influence of sludge pretreatment on nitrification of $\mathrm{A} / \mathrm{O}$ reactor removing phosphorus simultaneous precipitation. Biotec Biopro Eng 18(2): 313-320. doi:10.1007/s12257-012-0492-5

Doyle JD, Parsons SA (2002) Struvite formation, control and recovery. Water Res 36(16):3925-3940. doi:10.1016/S00431354(02)00126-4

Etter B, Tilley E, Khadka R, Udert KM (2011) Low-cost struvite production using source-separated urine in Nepal. J Water Res 45:852-862. doi:10.1016/j.watres.2010.10.007

Frost RL, Weier ML, Erickson KL (2004) Thermal decomposition of struvite: implications for the decomposition of kidney stones. J Therm Ana Cal 76:1025-1033. doi:10.1023/B:JTAN. 0000032287.08535.b3

Ganrot Z, Dave G, Nilsson E (2007) Recovery of N and P from human urine by freezing, struvite precipitation and adsorption to zeolite and active carbon. J Bio Tech 98:3112-3121. doi:10. 1016/j.biortech.2006.10.038

Ghosh GK, Mohan KS, Sarkar AK (1996) Characterization of soilfertilizer $\mathrm{P}$ reaction products and their evaluation as sources of $\mathrm{P}$ for gram (Cicer arietinum L.). J Nutr Cycl Agroecosyst 46:71-79. doi:10.1007/BF00210225

Government of Goa, Department of Agriculture website (2013) http:// www.agri.goa.gov.in/home URL:http://www.google.co.in/url?sa = $\mathrm{t} \& \mathrm{rct}=\mathrm{j} \& \mathrm{q}=\&$ esrc $=\mathrm{s} \& \mathrm{frm}=1 \&$ source $=$ web\&cd $=1 \&$ $\mathrm{cad}=$ rja \&ved $=0 \mathrm{CDAQFjAA} \& u r l=\mathrm{http} \% 3 \mathrm{~A} \% 2 \mathrm{~F} \% 2 \mathrm{Fwww}$. goa.gov.in $\% 2 \mathrm{Fpdf} \% 2 \mathrm{Fschemebydirectorateofaggri2011.pdf}$ \&ei $=$ jis2UdTYF8SPrgezloDwAg\&usg $=$ AFQjCNFIM9PHuKe CufnBGnQFeDiPF80vGg\&sig2 = OBVOClhNEIpPJHVLJRt49Q

Government of India, Ministry of Agriculture, Department of Animal Husbandry, Dairying \& Fisheries, New Delhi (2010-11) Annual report

Gunay A, Karadag D, Tosun I, Ozturk M (2008) Use of magnesit as a magnesium source for ammonium removal from leachate. J Haz Mat 15(6):619-623. doi:10.1016/j.jhazmat.2007.12.067

Huang HM, Xiao XM, Yang LP, Yan B (2010) Removal of ammonium as struvite using magnesite as a source of magnesium ions. J Water Pra Tech 5:1-9. doi:10.2166/wpt.2010.007

Krishnamurthi K, Dutta D, Sivanesan SD, Chakrabarti T (2004) Protective effect of distillate and redistillate of cow's urine in human polymorphonuclear leukocytes challenged with established genotoxic chemicals. J Bio Env Sci 17:247-256

Kumashiro K, Ishiwatari H, Nawamura Y (2001) A pilot plant study on using seawater as a magnesium source for struvite precipitation. Paper presented during the second international conference on recovery of phosphates from sewage and animal wastes, Noordwijkerhout, Holland

Lee SI, Weon SY, Lee CW, Koopman B (2003) Removal of nitrogen and phosphate from wastewater by addition of bittern. Chemosphere 51:265-271. doi:10.1016/S0045-6535(02)00807-X
Miles A, Ellis TG (2001) Struvite precipitation potential for nutrient recovery from anaerobically treated wastes. J Water Sci Tech 4:259-266

Pastor L, Mangin D, Barat R, Seco A (2008) A pilot-scale study of struvite precipitation in a stirred tank reactor: conditions influencing the process. J Bio Tech 99:6285-6291. doi:10. 1016/j.biortech.2007.12.003

Perera PWA, Han ZY, Chen YX, Wu WX (2007) Recovery of nitrogen and phosphorus as struvite from swine waste biogas digester effluent. J Bio Env Sci 20:343-350

Quintana M, Sánchez E, Colmenarejo MF, Barrera J, García G, Borja R (2005) Kinetics of phosphorus removal and struvite formation by the utilization of by-product of magnesium oxide production. Chem Eng J 11:45-52. doi:10.1016/j.cej.2005.05.005

Rahman MM, Liu Y, Kwag JH, Ra C (2011) Recovery of struvite from animal wastewater and its nutrient leaching loss in soil. J Haz Mat 186:2026-2030. doi:10.1016/j.jhazmat.2010.12.103

Raj ES, Kaliappan S, Adish Kumar S, Banu RJ (2012) Combinative treatment (thermal-anaerobic) of EBPR sludge for the enhanced release and recovery of phosphorus. Int J Env Eng 4(1/2): 93-105. doi:10.1504/IJEE.2012.048097

Raj ES, Banu R, Adish Kumar S, Kaliappan S (2013) Effects of sidestream, low temperature phosphorus recovery on the performance of anaerobic/anoxic/oxic systems integrated with sludge pretreatment. J Bio Tech 140:376-384. doi:10.1016/j.biortech.2013.04.061

Ryu HD, Kim D, Lee SI (2008) Application of struvite precipitation in treating ammonium nitrogen from semiconductor wastewater. J Haz Mat 156:163-169. doi:10.1016/j.jhazmat.2007.12.010

Ryu HD, Lim CS, Kang MK, Lee SI (2012) Evaluation of struvite obtained from semiconductor wastewater as a fertilizer in cultivating Chinese cabbage. J Haz Mat 221-222:248-255. doi:10.1016/j.jhazmat.2012.04.038

Sakthivel SR, Tilley E, Kai M Udert KM (2011) Wood ash as a magnesium source for phosphorus recovery from source-separated urine science of the total environment doi:10.1016/j. scitotenv.2011.12.065

Saunders WHM (1982) Effects of cow urine and its major constituents on pasture properties. N Z J Agric Res 25:61-68. doi:10. 1080/00288233.1982.10423373

Shu L, Schneider P, Jegatheesan V, Johnson J (2006) An economic evaluation of phosphorus recovery as struvite from digester supernatant. J Bio Tech 97:2211-2216. doi:10.1016/j.biortech. 2005.11.005

Song YH, Qiu GL, Yuan P, Cui XY, Peng JF, Zeng P, Qian F (2011) Nutrients removal and recovery from anaerobically digested swine wastewater by struvite crystallization without chemical additions. J Haz Mat 190(1-3):140-149. doi:10.1016/j.jhazmat.2011.03.015

Suzuki K, Tanaka Y, Kuroda K, Hanajima D, Fukumoto Y (2005) Recovery of phosphorus from swine wastewater through crystallization. J Bio Tech 96:1544-1550. doi:10.1016/j.biortech. 2004.12.017

Tilley E, Atwater J, Mavinic D (2008) Recovery of struvite from stored human urine. J Env Tech 29(7):797-806

Tilley E, Gantenbein B, Khadka R, Zurbrügg C, Udert K (2009) Social and economic feasibility of struvite recovery from Urine at the community level in Nepal. Presented at the international conference on nutrient recovery from wastewater streams, Vancouver, Canada. p 169-178

Uysal A, Yilmazel YD, Demirer GN (2010) The determination of fertilizer quality of the formed struvite from effluent of a sewage sludge anaerobic digester. J Haz Mat 181:248-254. doi:10.1016/ j.jhazmat.2010.05.004

Vance CP (2001) Symbiotic nitrogen fixation and phosphorus acquisition. Plant nutrition in a world of declining renewable resources. J Plant Phy 127(2):390-397. doi:10.1104/pp.010331 
Yetilmezsoy K, Sapci-Zengin Z (2009) Recovery of ammonium nitrogen from the effluent of UASB treating poultry manure wastewater by MAP precipitation as a slow release fertilizer. J Haz Mat 166:260-269. doi:10.1016/j.jhazmat.2008.11.025
Zeng L, Li X (2006) Nutrient removal from anaerobically digested cattle manure by struvite precipitation. J Env Eng Sci p 285-294. doi:10.1139/s05-027 